\title{
DIE PLEK VAN ISRAEL IN ONS TEOLOGIES-KERKLIKE BESKOUING
}

1. Die titel ${ }^{1}$ van hierdie verhandeling vra in die eerste plek om 'n korte begripsbepaling. Daarby laat ek in die midde, wat hier onder "ons" verstaan moet word, en ek sal ook nie uitwy oor die verbinding van kerk en teologie, soos dit in die formulering tot uitdrukking kom nie. Ons sal later nog wel 'n oomblik hierop moet teruggryp. Ons kan egter in geen geval wag met die beantwoording van die vraag: Wat verstaan ons in hierdie ondersoek onder "Israel" nie?

Dis gemaklik om te sê wat ons hier nie onder "Israel" verstaan nie. Ons bedoel op die oomblik met die naam "Israel" nie die staat Israel nie. Die leser sal daar nie aan twyfel nie, dat die skrywer met die grootste belangstelling en liefde die gebeurtenisse in Palestina sedert die beeindiging van die Britse mandaat in 1948 gevolg het. As dit nog nodig mag wees, kan sy boek oor Jerusalem ${ }^{2}$ as bewys daarvan strek. Maar selfs die grootste mate van geesdrif vir die jonge staat in die ou land mag ons tog nie daartoe verlei om Israel met die staat van daardie naam te vereenselwig nie. In die eerste plek is dit nog altyd so, en sal dit ook wel altyd so bly, dat die groot meerderheid van Israel as volk nie binnekant die grense van die staat Israel verblyf hou nie, en dat 'n belangrike deel van die geestelike kragte eerder in Amerika as in die Heilige Land sy uitgangspunt vind. ${ }^{3}$ Verrolgens merk ons op, dat die bestaan van daardie grootheid "Israel” nle volstrek van die bestaan van die staat Israel afhanklik is nie, al is die wisselwerking tussen die staat Israel en die Jodendom in die verstrooiing 'n buitegewoon interessante en boeiende skouspel. Dit is ' $n$ feit dat ' $n$ verhandeling met hierdie titel ,Die plek van Israel in ons teologies-kerklike beskouing" ook heel goed 'n jaar of twintig gelede geskryf kon word: dus lank voordat daar 'n staat Istael bestaan het.

Netsomin bedoel ons egter met die woord "Israel" 'n etnologiese grootheid. In die voorafgaande het ons een keer die woord ,,volk" gebruik, en op die verskil tussen die staat Israel en die volk van daardie naam gewys. Dit beteken egter nie, dat ons Israel net as een van die baie volke uit die wêreld en sy geskiedenis sien nie. Hierdie volke word in die Bybelse tale as gojim en ethnè aangedui. Hoewel daar in die geskiedenis van Israel oomblikke en tydperke was, waarin Israel volgens een van sy aspekte as ' $n$ volk in daardie sin aangemerk kon word, en in die O.T. Israel dan ook 'n paar maal, teen die reël wat ons as beginnende studente geleer het,

1) Die leser vind hier die lesing, deur die skrywer op 29 Februarie 1956 vir die Predikantevergadering te Pretoria gehou. Die formulering van die titel was van die skriba van daardie vergadering, Ds. D. DU Toîr, af komstig.

2) A. van SeLms), De verscheurde stad, 1956.

3) Dit geld sowel van die „Progressive Judaism" as van die aan die Jiddiesj vashoudende geestesstroming. 
'n goj genoem word 4 besien ons by ons ondersoek van vandag Israel uit 'n ander gesigshoek, van waaruit die woorde goj en ethnos juis die teengestelde aandui van wat ons bedoel.

Wie enigsins taalkundig geskool is, sal begryp dat ons dus Israel neem in die sin van 'am en laos, 'n menslike gemeenskap as draer van geestelike waardes, 'n gemeenskap wat aan die taak, hierdie waardes in die wêreld uit te dra, die sin van sy bestaan ontleen. Die goj, die ethnos, dra sy uiters betreklike - sin in homself en ken geen hoër taak as selfhandhawing nie. Die 'am, die laos, ontvang sy sin van bo, is dus 'n sakrale begrip; dit lewe kragtens godlike verkiesing, en stel homself tot 'n lewende offerande. ${ }^{5}$

Ons taal is nie by magte om die verskil tussen goj en 'am, tussen ethnos en laos, tot uitdrukking te bring nie. ${ }^{6}$ Hierdie onmag het noodlottige gevolge. Deur hierdie vereenselwiging van goj en 'am, wat nie met respektiewelik ,nasie en ,volk"' vertaal kan word nie ${ }^{7}$, het dit moontlik geword dat die Bybelleser die uitsprake van die Heilige Skrif oor die volk Israel verstaan as kwalifikasies van die gewone volke van die wêreld waartoe ook die Afrikanervolk behoort - en die blik op die uiters besondere posisie van Israel versluier word; tewens kry deur die vermenging van die twee begrippe die gewone volke, en ook die Afrikanervolk, 'n sakrale wyding wat hulle nie toekom nie.

Om nou tog in verstaanbare taal tot uitdrukking te bring, wat ons onder "Israel" in ons titel verstaan, wil ek die woord "Godsvolk" gebruik. Daaronder verstaan ons dan 'n gemeenskap van mense, wat in die gewone menslike geskiedenis optree, maar kragtens die verkiesende vrymag van God tegelyk 'n aktiewe taak in die heilsgeskiedenis gekry het, en sodoende 'n kritiese begrensing van alle geskiedenis trek. Soos reeds aangedui, vind hierdie Godsvolk sy oorsprong as sodanig in die verkiesende en roepende genade van God. Altans sou die benaming "Godsvolk" 'n godslasterlike pretensie wees. Maar omdat die verkiesing deur God aan die begin van Israel $\operatorname{staan}^{8}$, sal dit ook verder die bepalende faktor bly.

4) Gen. $18: 18$; Ps. 106:5; Jes. 60:22; Eseg. 35:10. Vir elk van die gevalle kan spesiale redes aangevoer word.

5) Vgl. J. KoopmaN): Wat zegt de Bijbel?, 1941, p. 7-21.

-) Ook die Griekse vertalers van die O.T. het hul moeilikhede daarmee gehad; dikwels is ethnos nie die weergawe van goj, en laos nie van 'am nie. 'n Treffende voorbeeld daarvan is Sirag 50:25, 26, waarvan die Griekse teks as volg lui : „Oor twee nasies (ethnos) vererg my siel hom, en die derde is geen nasie (ethnos) nie: hulle wat woon op die gebergte van Samaria, en die Filistyne, en die dwase volk (laos) wat in Sigem bly." Die Hebreeuse teks lui as volg: ,Oor twee nasies (gojim) vererg my siel hom, en die derde is geen volk ('am) nie: hulle wat Seir (seker beter lesing!) en Filistea bewoon, en die dwasie nasie (goj) wat in Sigem bly."

7) Die Afrikaanse vertalers is nie konsekwent in hul weergawe van goj met ",nasie" nie; sien bv. Ps. 106:5. In Afrikaans is daar geen duidelike verskil tussen ,nasie "en ,volk" nie.

8) Hierdie stelling bly staan onafhanklik van die uitslag van die debat tussen Galling en Vriezen oor die vraag of die verkiesing van die aartsvaders of wel die van die volk by die uittog uit Egipte primêr is. 
Israel kan dus nooit 'n strik genealogiese begrip wees nie. Dit staan God vry om ook van Filistyn, Tiriër of Moor te beslis dat hy in Sion gebore is ${ }^{9}$; die vrymag van God word deur geen bloedbande beperk nie.

Ons spreek dus van Israel as die Godsvolk, die uitverkore volk, die volk waarvan die geskiedenis heilsgeskiedenis is; van die weë van God met hierdie volk, sy volk, getuig die Heilige Skrif.

2. Daarby nader ons reeds tot die tweede punt, wat in hierdie verband bespreek moet word: die metode van ons ondersoek.

Daardie metode is feitlik reeds aangedui deur die woorde ,in ons teologies-kerklike beskouing" daarmee is gesê, dat ons Israel uit 'n bepaalde gesigshoek sien. Daardie gesigshoek is nie willekeurig deur ons gekies, sodat ons in die plek daarvan ook ' $n$ ander een kon inneem nie. Ons gesigshoek is bepaal deur wat ons is: lede van die Kerk, lidmate van die gemeenskap wat in Jesus die Christus bely.

Daarmee is 'n paar belangrike eienaardighede van ons gesigshoek aangegee, eienaardighede wat op die oog amper met mekaar in stryd is. In die eerste plek sê ons daarmee dat ons Israel nie beskou soos Israel homself teenwoordig beskou nie. Ons blik op Israel is 'n ander as wat Israel oor homself het. Ons beskou die selfgetuienis van Israel nie as die laaste woord oor die Godsvolk nie.

Aan die ander kant sal tog vrywel al ons gegewens, op grond waarvan ons 'n kerklik-teologiese beskouing van Israel kan opbou, van Israelitiese herkoms wees. Ons sou van Israel amper niks weet was Irsael nie as getuie van sy eie bestaan sou opgetree het nie. Wat sou ons van Israel in staat wees om te sê buite die Bybel ${ }^{10}$, Flavius Josefus, die Misjna en die Talmuds om? 'n Aantal sporadiese vermeldings in Egiptiese naamlyste ${ }^{11} \mathrm{en}$ Assiriese annale ${ }^{12}$, 'n minagtende korte beskrywing, vol misverstande, by Tacitus en nog wat sinspelings by ander outeurs - dis al. ${ }^{13}$ Ons is dus aangewys op die selfgetuienis van Israel - dieselfde selfgetuienis waarvan ons net nou gesê het dat dit nie as die laaste woord beskou kan word nie.

Met hierdie antinomie hang 'n tweede saam, wat ons reeds aangeroer het, toe ons gespreek het van die Kerk as die gemeenskap wat in Jesus die

P) Ps. 87:4 volgens die uitleg wat die kerke blykens hul paslamberymings daaraan gegee het.

10) Die enigste Bybelskrywer van nie-Israelitiese herkoms is Lukas, vgl. Kol. 4:14 met 11.

11) Die naam Israel kom net op die Menefta-stele voor; sien verder J. SIMON), Handbook for the study of Egoptian topographical lists relating to Westem Asia, 1937.

12 ) Die noordelike ryk heet daar dikwels ,die huis van Omri"; die suidelike ryk "Juda". Die benaming „Israeliet" kom maar selde voor. Babiloniese gegewens ontbreek. Om volledig te wees, sou mens ook nog die Mesa-inskripsie moet noem.

13) Sien F. M. TH. DE LAGRE BöHL, Die Juden im Utteil der griechischen und romischen Schriftsteller, 1914, herdruk in Opera Minora, 1953, p. 101-133; 485.486. Die dokumente van Qumraan en naby geleè vindplekke behoort natuurlik tot die selfgetuienis van Israel. 
Christus bely. Die naam Jesus, en die aardse gestalte wat daardie naam gedra het, is onlosmaaklik met Israel verbind. Die titel Christus en al wat dit inhou, verloor sy sin sodra ons dit van Israel losmaak. 'n Mens kon net so goed die titel Paus losmaak van die Roomse Kerk as wat ons die woorde Christus en Messias los kon maak van Israel. 'n Christus buite Israel, los van Israel, is 'n onbestaanbaarheid.

Maar sodra ons dit gesien het, besef ons ook dat ons in die tweede antinomie beland het: Want hierdie Jesus, wat deur ons as die Christus van Israel bely word, is juis deur Israel verwerp - en kon ook net deur Israel verwerp word. Hy word deur al die nasies van die wêreld gehuldig of sal nog deur hulle gehuldig word -, maar Israel, die enigste volk wat aan hom die Christus-titel kon toeken, huldig hom nie. Watter haglike toestand sodoende ontstaan het, kan ons die beste verstaan deur ons 'n oomblik voor te stel, dat bv. die koning van Denemarke orals op die wêreld as koning van Denemarke sou erken word - maar net in Denemarke self nie. Outomaties sou dit die hele wêreld in 'n teenstelling tot Denemarke bring - maar die koning van Denemarke is self 'n Deen! Sal hy hom deur uitlanders aan sy volk laat opdring? Sal hy die vyandskap van die hele wêreld teen sy eie volk verwelkom? Sal hy hom onder die vyande van sy volk skaar? Of moet hy aan die kant van sy eie volk bly staan, aan die kant van sy eie mense wat hom nie aan hulle kant wil laat staan nie?

Hierdie uiters delikate situasie ${ }^{14}$ ontstaan, sodra ons bely dat Jesus die Christus is, die Koning van Israel. Dis duidelik dat ons eerste antinomie, die feit dat ons enersyds vir ons beskouing van Israel afhanklik is van Israel se selfgetuienis, en dat ons andersyds daardie selfgetuienis nie as die hoogste gesag kan beskou nie, dat hierdie eerste antinomie sy diepere agtergrond vind in die tweede: dat die Koning van Israel as sodanig slegs buite Israel erken word.

Hoe het dit so gekom? Tot op sekere hoogte kan ons sê dat hier 'n historiese ontwikkeling agter lê. Daaruit volg dus dat ons geskiedkundig moet gaan dink. Wysgerige spekulasie kan geen antwoord gee op die vraag, wat 'n Israel sonder Christus of 'n Christus sonder Israel aan ons stel nie. Maar aangesien ons in Israel, soos ons gesien het, met die Godsvolk te doen het, en sy geskiedenis die oordeel oor alle geskiedenis bevat, aangesien die geskiedenis van Israel ook heilsgeskiedenis is, sal die historiese wetenskap as sodanig, die beskrywende arbeid van Tacitus tot Toynbee, ook geen bevredigende verklaring van die probleem kan gee nie. ${ }^{15}$

14) Dit was die situasie waarin die Bourbons hulle na 1792 bevind het, en wat deur hulle seker nie delikaat behandel is nie.

15) Dis trouens ook bekend dat hierdie twee groot geskiedskrywers selfs die historiese Israel nie bevredigend kan beskrywe nie. 
Dan bly daar dus geen ander benadering oor as die op grond van die Heilige Skrif nie. Dit is uit algemeen geskiedkundige oogpunt die selfgetuienis van Israel, maar tegelyk is dit oneindig meer : die oorkonde van Gods weg met Israel, en so dus die enigste werklike bron vir ons kennis van die heilsgeskiedenis. Van uit die heil en sy geskiedenis, die verwerkliking van die raad van God, moet Israel verstaan word.

Maar as ons nou sê dat ons die probleem van Israel skriftuurlik wil benader, het ons daarmee ons metode nog nie volledig aangedui nie. 'n Kerklike beskouing van Israel, dit wil sê 'n beskouing wat uitgaan van wat aan ons in die Kurios, in die Here Jesus Christus, gegee is, benader die Heilige Skrif van Christus uit. ${ }^{16}$ Christus is die principium canonicitatis, en hierdie Reformatoriese beginsel bepaal nie maar net die omvang van die Kanon nie, maar ook ons benadering van die onderdele daarvan.

Ons sou met die Ou Testament niks te doen het nie, as ons nie uit die Nuwe Testament sou leef nie. Ons benader die O.T. van die N.T. uit, en nie omgekeerd nie. Ons glo Christus nie om die Skrif ontwil nie, maar ons glo die Skrif om Christus ontwil. Ons vind Christus in die N.T., en vandaar uit kan ons teruggaan na die O.T., om daar in profesie en voorafskaduwing die Messias weer te vind. Sonder die N.T. is dit vir ons onmoontlik om die O.T. Christelik te verstaan.

Dit beteken dus dat ons as Kerk en as teoloë nie regstreeks na die O.T. mag gaan nie, maar dit altyd oor die weg van die N.T. moet bereik. Ook histories gesien is dit nie anders as billik nie. Die O.T. is nie vir ons geskryf nie, maar vir Israel, en dit raak ons net in sover as ons deur die Christus van Israel ook deel aan Gods weg met Israel kry.

Dit beteken dus ook dat ons geen gegewens uit die O.T., wat in die N.T. nie meer opgeneem word nie, regstreeks, buite die N.T. om, op ons lewe en verwagting mag betrek nie. Doen ons dit tog, dan handel ons nie maar net asof daar geen geskiedenis bestaan nie, maar ons ontken selfs die prinsipiële betekenis van die feit dat heilsgeskiedenis geskiedenis is. ${ }^{17}$ Dit is die kettery van die Biblisisme, wat nie so onskuldig is as wat party mense dink nie. Die onderstelling en tegelyk konsekwensie daarvan is dat die Christus agter die Skrif verdwyn. ${ }^{18}$.

Hieruit volg dat ons vir ons beskouing van Israel na die N.T. moet luister. Wat ons in die O.T. vind, kan daardie beskouing bevestig en illustreer, maar nie wysig nie.

Vir die plek van Israel in die toekoms moet ons dus veral nie na die sogenoemde „onvervulde profesieë" gaan soek nie. Die uitdrukking, en

16) As die leser dit Christomonisme wil noem, dan is die skrywer bly dat hy dieselfde verwyt as die grootste teoloog van hierdie eeu mag dra.

17) Daarmee word dan die enigste singewing van die menslike geskiedenis onmoontlik.

18) Dan gaan ons met die I.C.C.C. van ,skrifgelowig" in plaas van met die geloofsbelydenis van „Christusgelowig" praat. 
die gedagte wat daaragter lê, is Judaisties en sektaries. Volgens die N.T. en die belydenis van die Kerk is al die beloftes van God in Christus vervul. Wie dit ontken, misken die volheid in Christus. As die hele O.T. nie in Christus vervul sou wees nie, sou dit sin kan hê om buite Christus om die Joodse religie voort te set. Dan sou die Kerk nie die plig hê om Christus aan die Jode te predik nie. Want Christus sou dan nie die een en al ook van die O.T.-iese heilsgeskiedenis wees nie. Daar sou heilsbeloftes, en dus heil, buite Hom om wees.

Die gespeur na „onvervulde profesieë" sien nog 'n ander ding oor die hoof, naamlik dat profesie geen voorspelling is nie. Hierdie saak is so belangrik, dat dit met 'n uitermate eenvoudige en huislike voorbeeld toegelig moet word. As ek 'n seun wat op die punt staan om ondeuende dinge te doen, verseker: „Ek gaan jou klap”, en hy word daardeur van sy bose opset afgeskrik, dan is die woorde „Ek gaan jou klap" nie 'n onvervulde profesie nie, ook al is dit waar dat ek hom naderhand nie geklap het nie. Inteendeel, hulle het so kragdadig gewerk, dat ek nie meer hoef te klap nie. ${ }^{19}$ Hulle is dus werklik vervul, het hulle sin en bestemming bereik. As voorspelling geneem het hulle nie uitgekom nie, maar hulle was geen voorspelling nie: hulle was geen objektiewe mededeling oor die toekoms nie, maat ' $n$ middel om daardie toekoms te beinvloed.

Dieselfde kan mutatis mutandis van die O.T.-iese profesie gesê word. Deur sy woord vorm die Here die toekoms. Die Here doen geen mededelinge nie, maar gee deur belofte en bedreiging rigting aan die lewe van sy volk. $\mathrm{Al}$ die beloftes en bedreiginge is, of dit daar met soveel woorde aan toegevoeg word ofte nie, voorwaardelik. Die belofte vra om geloof, die bedreiging om ontsag. Waar geloof ontbreek, word die belofte nie toegeëien nie; waar ontsag ontbreek, word die bedreiging nie ter harte geneem nie. Sonder geloof word die belofte tot 'n oordeel; waar ontsag is, word die bedreiging tot ' $n$ seëning.

Dis alles eintlik vanselfsprekend, en so nodig kan dit nog duidelik aan die hand van die boek Jona gedemonstreer word. Niemand sal beweer dat die prediking van Jona teen Nineve: „Nog veertig dae, dan word Nineve verwoes" tot die onvervulde profesieë behoort nie - of ons sou al net so dwaas moes wees as Jona self, wat hom oor die barmhartigheid van God beklaag het. ${ }^{20}$ Juis deur dat die bedreiging gewerk het, sy bestemming bereik het, word die voorspelling, wat 'n oppervlakkige mens daaruit kon aflei, nie verwerklik nie.

Om hierdie twee redes, die algenoegsaamheid van Christus en die voorwaardelike karakter van alle profesie, verwerp ons dus elke gevolgtrekking wat uit die O.T. buite die N.T. om ten aansien van Israel gemaak kon word.

\footnotetext{
19) Hieruit volg tewens dat die onderskeiding tussen heils- en onheilsprefesie weinig sin het en seker nie as histories-litterêre maatsnoer mag gebruik word nie.

10) Jona $4: 2$.
} 
3. Metodies lyk dit die beste om die bespreking van die N.T-iese gegewens met die oudste deel van die N.T. te begin, en dus met die briewe van die heilige Apostel Paulus. Afgesien van ander voordele is dit altyd 'n middel om die valse teenstelling, wat dikwels tussen Jesus en Paulus gemaak word $^{21}$, te vermy.

Oor die onderwerp "Israel in die Pauliniese briewe" sou gemaklik 'n lywige boek geskryf kan word, veral as 'n mens daarby op die geskiedenis van die eksegese van bepaalde passasies sou ingaan. Ons bepaal ons in hierdie kort opstel net tot 'n paar hoofpunte, in die onderstelling, dat sowel die leer van die eenheid van die Heilige Skrif as ook die energie van die Pauliniese denkwyse vir ons as 'n waarborg kan dien dat die ander punte gemaklik in die algemene lyn ingevoeg kan word.

In I Thess. 2:14-16 — soos bekend behoort die briewe aan die gemeente van Thessalonika tot die oudste Paulina - spreek die Apostel baie bitter en skerp oor die Jode, wat die Evangelie nie wou aanneem nie: "... die Jode wat ook die Here Jesus en hulle eie profete gedood en ons vervolg het en God nie behaag nie en teen alle mense gekant is, deurdat hulle ons verhinder om tot die heidene te spreek dat hulle gered kan word, sodat hulle die maat van hulle sondes gedurig vol kan maak. Maar die toorn het oor hulle gekom tot die einde toe." Ons wil in die besonder op die laaste woorde die aandag vestig: "Maar die toorn het oor hulle gekom tot die einde." Dit wil sê: hulle lê onder die orgè theou, en wel "tot die einde", wat beteken: 'n volkome oordeel is oor hulle gevel. Ons kan dit nie verstaan as ' $n$ sinspeling op die verwoesting van Jerusalem in 70 na Chr. nie; dit sou die omkering van die hele chronologie van die lewe van Paulus beteken; en om die woorde as 'n later toevoeging te beskou is ook nie noodsaaklik nie. In die feit dat die Jode die Apostels probeer verhinder om die Evangelie aan die heidene te verkondig, sien Paulus die oordeel oor hulle voltrek: die verharding is die bewys van die volkome oordeel, van die verwerping.

Hierdie taal is duidelik en daar is ' $n$ reeks van uitsprake in die Corpus Paulinum wat in dieselfde rigting wys. Ek noem hier slegs die gelykstelling van Jerusalem met Hagar in Gal. 4:25; ${ }^{22}$ en die feitlike parallelie tussen Jode en heidene in I Kor. 1:22: „Die Jode vra 'n teken en die Grieke soek wysheid, maar ons verkondig Christus wat gekruisig is, 'n struikelblok vir die Jode en dwaasheid vir die Grieke." Hier is die vra om 'n teken 'n uiting van ongeloof, en dus 'n blyk van die verwerping deur God. Dieselfde gelykstelling van Jood en heiden vind ons in Rom. 3:9, sodat die hele requisitorium van Rom. 3:10-18 - oorgeneem uit die O.T., die self-

21) Bv. Jesus as Jood, Paulus as Hellenis; Jesus as die sagmoedige, Paulus as die strenge; ens. Elk van die teenstellings kan uit die eie woorde van Jesus en van Paulus gemaklik weerlê word. As Paulus Jesus nie verstaan het nie, dan het nooit 'n mens die prediking van die Here verstaan nie.

22) En wel met die Hagar wat uitgeworpe word, Gal. 4:30. 
getuienis van Israel! - op Israel van toepassing gemaak word. Selfs die besnydenis, die teken van die verbond onder die ou bedeling, word met die woord „versnyding" in Filipp. 3:2 onder die oordeel gebring.

Maar om nou tot die Thessalonisense terug te kom: in II Thess. 2:4 miskien is die tweede brief in tydsorde die oudste - lees ons dat, ,die mens van sonde", die teënstander wat homself verhef bo elkeen wat God genoem word of voorwerp van aanbidding is - die antichris, kan ons wel sê, hoewel daardie woord nie by Paulus voorkom nie - , in die tempel van God as God sal sit en voorgee dat hy God is." Daardie tempel van God kan hier geen ander wees as die tempel te Jerusalem nie ; ${ }^{23}$ toe Paulus geskryf het; het dit nog gestaan, en dit is deur Paulus nieteenstaande alles wat hy teen die Jode en teen Jerusalem en teen die ,,versnyding” inbring, as die tempel van God erken. In daardie selfde lyn lê ook 'n lange reeks van uitsprake van die Apostel. Die gelykstelling van Jode en Grieke in I Kor. 1:22, wat ons reeds aangehaal het, strek nie net tot die oordeel oor die Jood nie, maar stel ook die moontlikheid van genade: „... maar vir die wat geroep is, Jode sowel as Grieke: Christus, die krag van God en die wysheid van God." Dis nie sonder rede dat die Jode hier eerste genoem word nie; die Apostel hou vas aan die primaat van Israel, juis ook in verband met die Evangelie: ,... want dit is 'n krag van God tot redding vir elkeen wat glo, eerste vir die Jood en ook vir die Griek." ${ }^{24}$ Hy hou vas aan die ontsaglike bevoorregting van Israel bo alle nasies: „Wat is dan die voordeel van die Jood? Of wat is die nut van die besnydenis? Groot, in alle opsigte: ten eerste tog seker dat aan hulle die woorde van God toevertrou is. Want wat maak dit as sommige ontrou geword het? Sal hulle ontrou miskien die getrouheid van God vernietig? Nee, stellig nie! ${ }^{25}$ In dieselfde brief, waarin hy die „versnyding" hoon, roem hy self in die feit dat hy ,op die agste dag besny" is (Filipp. 3:5).

Met ' $n$ hedendaagse term sou ons dus van die dialektiese houding van die Apostel teenoor Israel kan spreek: aan die een kant sien hy die toorn van God oor Israel geopenbaar, aan die ander kant bly hy nietemin Israel as die Godsvolk beskou. Dis begryplik dat die Apostel nie by hierdie tweespalt as sodanig bly staan het nie. Die eenheid van die menslike gees vra om 'n oplossing van die dialektiek. Die dialektiek is altyd die resultaat van die waarneming van die presente werklikheid; dis 'n teken van werklikheidsin om nie te dink dat die situasie, waarin die mens verkeer, volgens een beginsel verklaar kan word nie. Maar omdat die menslike gees tog na 'n oplossing van die dialektiek soek, sal hy daartoe lyne trek wat buitekant die presente en waarneembare werklikheid sal loop. Daarby is teoreties twee moontlikhede denkbaar. Die een is dat die ondersoeker sy gedagtes gaan rig op wat agter die waarneembare werklik-

$\left.{ }^{23}\right)$ 'n Ander betekenis het die uitdrukking in I Kor. 3:16, 17;6:19; II Kor. 6:16; Ef. 2:21.

24) Rom. 1:16.

$\left.{ }^{25}\right)$ Rom. 3:1-4. Die vraag kan opgewerp word, of 'n Jood, wat Christen word, aan sy kinders die besnyenis moet onthou. 
heid lê; die ander is dat hy van die presente na die toekomstige werklikheid oorgaan. Om Kantiaans te praat: ${ }^{26}$ ons kan in so 'n geval in die ruimte of in die tyd skematiseer. Wie probeer om agter die waarneembare werklikheid deur te dring, skematiseer in die ruimte; wie tot die toekoms sy toevlug neem, skematiseer in die tyd.

Ons keer terug tot Paulus. Tot oplossing van sy dialektiese verhouding tot Israel kan hy agter die waarneembare werklikheid deurdring: dan onderskei hy die Israel na die vlees van die Israel na die gees. Die besnydenis word dan 'n ,sogenaamde besnydenis wat in die vlees met hande verrig word" (Efes. 2:11), en Israel heet "Israel na die vlees" (1 Kor. 10:18). Ten onregte word die laaste tyd deur wat 'n mens met 'n onaangename term Judaistiese Christene kon noem, herhaaldelik beweer dat die begrip ,geestelike Israel” nie Bybels is nie. As ons I Kor. 10:1: ,want ek wil nie hê, broeders, dat julle nie sou weet nie dat ons vaders almal onder die wolk was en almal deur die see deurgegaan het" vergelyk met die 18de vers van dieselfde hoofstuk „Let op Israel na die vlees," kan ons geen ander gevolgtrekking maak nie as dat die heidene in Korinte wat tot die geloof in Christus gekom het, deur Paulus as die nasate van ,die vaders" wat "onder die wolk" was, beskou is. Aangesien hulle geen liggaamlike band met die eerste Israelitiese generasie na die uittog gehad het nie, moet dit wel die bedoeling wees, dat hulle op geestelike wyse nasate van die bevryde volk was. So staan dit tog ook aangedui in Gal. 3:29: „En as julle aan Christus behoort, dan is julle die nageslag van Abraham." Dan is die "Jerusalem daarbo" „die moeder van ons almal," d.w.s. sowel van gelowiges uit die Jodedom as van gelowiges uit die heidendom (Gal. 4:26). Dit kan nie ingesien word, waarom die Apostel, as hy die waarneembare Israel „Israel na die vlees" noem, die gemeente van Christus nie „Israel na die gees" sou noem nie. Dit volg in ieder geval duidelik uit Gal. 4:29: ,,soos destyds hy wat na die vlees gebore is, hom wat na die Gees was, vervolg het, so is dit nou ook," vgl. ook Filipp. 3:3, waar dieselfde teenstelling tussen Gees en vlees ten aansien van Israel woorkom.

Maar behalwe hierdie deurbraak na die geestelike agter die waarneembare vind ons by Paulus ook die skematisering in die tyd. Ek het die oog op sy vermaarde betoog in Rom. 9-11. Nadat hy daarin nog ' $n$ keer, in ooreenstemming met die grondgedagtes van die hele brief, sowel die verkiesing as die verwerping van Israel gestel het, en 'n oomblik weer die skematisering in die ruimte, die deurbraak na die geestelike, toegepas hat: ,hulle is nie almal Israel wat uit Israel is nie ... nie hulle is kinders van God wat die kinders van die vlees is nie" 27 onderneem hy teen die einde

26) Dit klink by die gedruis van hedendaagse filosofieë as 'n stem uit die graf. Maar die skrywer het nog geen ander wysbegeerte gevind wat vir hom 'n bruikbare wetenskapsleer oplewer nie. Iets anders as 'n wetenskapsleer sal hy vir die filosofie nooit vra of aanvaar nie.

27) Rom. 9:6, 8 . 
van hierdie hoofafdeling van sy brief die skematisering in die tyd deur die befaamde blik op die toekoms: „Want ek wil nie hê, broeders, dat julle hierdie verborgenheid nie moet weet nie, sodat julle nie eiewys mag wees nie: dat die verharding ten dele oor Israel gekom het totdat die volheid van die heidene ingegaan het; en so sal die hele Israel gered word". ${ }^{28}$

Ek kan nie saamstem met die opvatting van die jongste Neocalvinistiese eksegete, dat in hierdie teks onder ,die hele Israel" die gelowige Jode (soos Paulus self) en die gelowige nie-Jode verstaan moet word nie. Dit is veral moeilik aanvaardbaar as ons daarby vers 31 vergelyk: ,,so het hulle ook nou ongehoorsaam geword deur die barmhartigheid aan julle, sodat hulle ook barmhartigheid kan ontvang." Die barmhartigheid wat hulle kan ontvang, is duidelik 'n toekomstige feit; dit kan nie sien op die barmhartigheid wat Paulus en ander Christene uit die Jode reeds ontvang het nie. Die werkwoordsvorm vir ,barmhartigheid ontvang", aoristus conjunctivus, wys nie op wat reeds ' $\mathrm{n}$ feit is nie, maar op wat kan plaas vind. Die „nou", wat die beste handskrifte daaraan toevoeg, dui nie die hede, maar die moontlikheid in die toekoms aan. 'n Paar teksgetuies het in plaas daarvan ,later"; hoewel dié lesing seker nie oorspronklik is nie, vertolk dit die bedoeling redelik getrou, al word die tyd daardeur wat langer gerek as die Apostel in sy haas na die einde self verwag het. In ieder geval is dit duidelik dat die Apostel verwag, dat Israel as 'n geheel sy Christus sal gaan bely.

Altwee skematiserings het iets onbevredigends: die spiritualisering van die begrip Israel is nouliks uit die O.T. regverdigbaar. Ons kan natuurlik na tekste soos Ps. 87:4 of Jes. 57:3 verwys, maar dieselfde tekste kon net so goed deur Paulus se Judaĩserende teenstanders aangehaal word ter ondersteuning van hul eis, dat die heidene eers in Israel opgeneem moet word, voor hulle as lidmate van die gemeente erken kon word. Die verwysing na die toekoms is vir ons, wat veel meer as die Apostel Paulus gewoon is om aan afsonderlike mense te dink, verre van bevredigend, omdat ons by die uitdrukking ,die hele Israel" geneig is om te vra: En hoe staan dit dan met die Jode, wat in hul verharding gesterf het? Die redding van die hele Israel in die jaar 1956 maak vir ons die lot van die afsonderlike Israeliete in die voorafgaande eeue nog nie begryplik nie.

Anderkant moet dit erken word dat daar geen ander moontlikheid bestaan om die godlike sake - en die Apostel worstel hier om die godlike raadsplan te verstaan - met die menslike verstand te benader as deur die skematisering in tyd of ruimte nie. Wat buitekant tyd of ruimte lê, is vir ons onbegryplik. Ons moet nie maar net sê dat die Apostel sover gegaan het as 'n mens in hierdie sake kan gaan nie, maar ook dat as hy verder sou gegaan het, ons hom nie kon gevolg het nie. As daar deur 'n spesiale woord-openbaring 'n vollediger uitbalansering van die dialektiek gegee

${ }^{28)}$ Rom. 11:25, 26 . 
was, sou dit 'n nuttelose openbaring wees, altans nutteloos vir mensekinders. Met die Apostel weet ons, dat in die ewigheid ,onuitspreeklike woorde" gehoor word; maar ons weet ook, dat 'n mens die woorde nie mag uitspreek nie. ${ }^{29}$ Verder as dialektiek en skematisering kom ons hier op aarde ook in die Christelike teologie nooit nie.

Gaan ons nou van die Pauliniese gegewens na 'n paar ander groepe van N.T.-iese boeke toe, dan sal ons dieselfde dialektiese houding ook daar aantref. Kortheidshalwe doen ons net 'n paar grepe. Dit sal niemand verwonder dat in die boek van die Handelinge, waarin die Apostel Paulus so ' $n$ groot plek inneem, en wat deur sy leerling Lukas opgestel is, dieselfde dialektiek gevind word nie. Aan die een kant is daar die woord van Petrus: "Julle is kinders van die profete en van die verbond wat God met ons vaders gesluit het," waarin die verbond van God met Israel erken en benadruk word, ${ }^{30}$ vergelyk ook die ander woord van Petrus: „Want die belofte kom julle toe en jull $€$ kinders". ${ }^{31}$ Aan die ander kant is daar 'n veelvuldige en aangrypende aanklag teen die gedrag van die waarneembare Israel, sowel te Jerusalem as te Damaskus, in Pisidië, te Listra, Thessalonika, Korinthe en opnuut te Jerusalem. En ook die skematisering, altans dié in die tyd, ontbreek nie geheel nie: in 3:19-21 hoor ons vermoedelik 'n eggo van Rom. 11:25-32, wat by Lukas as leerling en begeleier van Paulus ook in die geheel nie verwonderlik is nie.

In die sinoptiese Evangelies vind ons die dialektiese benadering telkens terug. Die doel van Christus se aardse omwandeling is om Homself as die Christus van Israel te openbaar. Vandaar die woord - vir ons so moeilik aanvaarbaar - van Christus tot die Kananese vrou: „Ek is net gestuur na die verlore skape van die huis van Israel." 32 Maar in dieselfde Evangelie vind ons die woord: „Baie sal kom van ooste en weste en sal saam met Abraham en Isak en Jakob aansit in die koninkryk van die hemele. Maar die kinders van die koninkryk sal uitgedryf word in die buitenste duisternis. Daar sal geween wees en gekners van die tande."

Tal van gelykenisse, wat ons gewoonlik individualisties uitlê, soos die van die ryk man en die arm Lasarus, kan miskien eerder in verband met die verhouding van Israel tot die heidene verstaan word. Dis seker die geval by die gelykenis van die arbeiders in die wingerd, soos duidelik blyk uit die slotsom, wat die ondergang van Jerusalem aankondig: „Hy sal kom en daardie landbouers ombring en die wingerd aan ander gee. En toe hulle dit hoor, sê hulle: Nee, stellig nie!" Uit hierdie reaksie blyk dat hierdie gelykenis beter as die meeste ander verstaan is.

Orals, bv. in die geskiedenis van die hoofman te Kapernaüm, in die verhouding van die Here Jesus tot tempel, tempelbelasting, Jerusalem, die

\footnotetext{
9) II Kor. 12:4.

10) Hand. 3:25.

31 Hand. 2:39.

22) Matth. 15:24.

13) Matth. $8: 11,12$.
} 
O.T.-iese wet, ens., vind ons dieselfde dialektiese verhouding. Wat ons, sover as die skrywer dit op die oomblik kan sien, nie aantref nie, is die poging tot oplossing deur skematisering. Die Evangeliste en die gemeenteteologie wat hul geskrifte beïnvloed het, het in die dialektiek self bly staan.

Dieselfde merk ons in die Johanneiese geskrifte, sowel die Evangelie as die Openbaring, op. Al weer noem ons net 'n paar tekste. Uit die Evangelie Joh. 4:22: „Die saligheid is uit die Jode." Maar tegelyk hoor ons ook $8: 44$ : ,Julle het die duiwel as vader." Uit die Openbaring: In 11-8 word Jerusalem genoem: ,die groot stad wat geestelik genoem word Sodom en Egipte, waar ook onse Here gekruisig is. Maar dieselfde stad heet in 20:9: „Die laer van die heiliges en die geliefde stad." Die Jodedom heet in 2:9 'n sinagoge van Satan, maar die siener aanskou twaalf maal twaalf maal duisend - drievoudig die getalle van uitgebreidheid en volkomenheid verseëldes, uitverkorenes en verlostes, af komstig uit alle stamme van Israel. ${ }^{34}$

4. Vir ons teologies-kerklike beskouing bly daar, gesien die eenstemmigheid van die N.T.-iese getuienis, niks anders oor nie as om daardie selfde dialektiese houding teenoor Israel in te neem: aan die een kant beaam ons, wat die hele N.T. betuig: deur die verwerping van die Christus het Israel „die raad van God teen hulleself verwerp," sodat dit onder die oordeel van God lê. Die uiterste konsekwensie daarvan sou 'n woord uit die Psalms kan wees: ,,Sou ek die nie haat wat vir U haat, en 'n afsku hê van die wat teen $U$ opstaan nie? Ek haat hulle met 'n volkome haat; vyande is hulle vir my!"35 Aan die ander kant beaam ons net soseer wat die Apostel Paulus skrywe: ,,dat dit vir my 'n groot droefheid is en 'n onophoudelike smart vir my hart. Want ek sou self kan wens om terwille van my broers, my stamgenote na die vlees, 'n vervloeking te wees, weg van Christus af. Hulle is Israeliete aan wie die aanneming tot kinders behoort en die heerlikheid en die verbonde en die wetgewing en die erediens en die beloftes; aan wie die vaders behoort, en uit wie die Christus is na die vlees - Hy wat bo alles is, God, lofwaardig is in ewigheid."36

Die vraag kan gestel word: Moet ons die Apostel Paulus volg in sy pogings om te skematiseer? Die antwoord is eenvoudig: die, wie se lot dit is om te strewe na 'n eenheid van konsepsie, dié moet dit doen. Hierdie moeilike besigheid het God volgens die Prediker in die hart - altans van party - mense gelê, om hulle daarmee af te tob. Ander pogings as wat ons reeds by Paulus gevind het, kan nie onderneem word nie. Ons het dit glo reeds aangetoon: 'n mens kan by sy skematiserings net die skematisering in die tyd, of die in die ruimte kies. 'n Derde word nie gegee nie.

34) Openb. 7:3-8.

ss) Ps. 139:21, 22.

se) Rom. 9:2-5. 
Die volgende vraag sal wees: Is daar iets wat die een, die konsepsie van 'n geestelike Israel, verkieslik maak bo die ander, die blik op die toekoms? Hierdie vraag beantwoord ons in ontkennende sin. Die twee staan gelyk in hul betreklike reg en betreklike onbevredigendheid. Die Apostel self sou die eerste wees om ons te verseker dat die laaste woord nie deur hom gesê is nie, maar deur God in Christus gespreek, gedoen sal word.

Miskien is daar by die leser nog 'n vraag, en dis seker nie die laaste, eerder amper die eerste: Watter betrekking het dit alles op die staat Israel?

Die antwoord op daardie vraag kan die beste in die vorm van 'n opdrag gegee word: Pas dieselfde dialektiek, wat ons in die N.T. gevind het, ook op daardie staat toe. Die staat Israel is nie los van die volk, ook nie van die Godsvolk nie; maar dis daarmee ook nie ident nie. Of die stigting van die staat Israel ' $n$ middel in die hand van God is om sy raad ten aansien van sy volk te volvoer, sal die toekoms, d.w.s. God leer. Persoonlik glo ek dit. Maar selfs al sou ek dwaal in my liefde vir die Godsvolk en die staat Israel, sou ek dit tog beter ag om in liefde te volhard as om in onaandoenlikheid te sterf.

A. van Selms. 